\title{
Effect of Jeevamrutham on the Growth and Development of Amaranthus Viridis
}

\author{
Dr. Sailaja. V. \\ Assistant Professor of Zoology \\ Vikrama Simhapuri University P.G. Centre \\ Kavali, SPSR Nellore District \\ $\&$ \\ Dr. Seethamma. G. \\ Lecturer in Zoology \\ Government College for Men, Kurnool \\ $\&$ \\ Dr. Madhava Reddy \\ Associate Professor \\ Department of Physiotherapy \\ Kugler Physiotherapy Degree College \\ Guntur, Andhra Pradesh, India
}

\begin{abstract}
Organic farming is a holistic agricultural system that enhances soil quality. Amaranth viridis is a popular a nutritious leaf vegetable that contain gluten-free grain which provides plenty of fiber, proteins and micronutrients which is used in herbal medicine. An organic fertilizer called Jeevamrutham is developed by using cow dung, cow urine, jiggery and pulses flour. Application of this fertilizer Amaranthus fields enhanced the physicochemical properties of the soil such as $\mathrm{pH}$, EC, N, P, K, and organic carbon content. Microbes such as Azospirillum and Actinomycetes are enhanced in experimental soil. The quantity of phytohormones like indole acetic acid, Gibberlic acid, Abscisic acid and kinetin are also increased. In total there is an increase in biomass, shoot length and root length in Amaranthus Viridis plant with Jeevamrutham. Thus, Jeevamrutham can be efficiently used organic fertilizer to improve growth and development and yield of Amaranthus Viridis.
\end{abstract}

Keywords: Organic Farming, Jeevamrutham, Soil Fertility, Amaranthus Viridis.

\section{Introduction}

Amaranthus Viridis is an annual herb with an upright, light green stem that grows to about $60-80 \mathrm{~cm}$ in height. Numerous branches emerge from the base, and the leaves 
are ovate, $3-6 \mathrm{~cm}$ long, $2-4 \mathrm{~cm}$ wide, with long petioles of about $5 \mathrm{~cm}$. The plant has terminal panicles with few branches, and small green flowers with three stamens (Tanaka \& Van Ke, 2007). The plant is often harvested from the wild as a source of food and medicines for local use. It is sometimes cultivated in the Tropics for its edible leaves and is often sold in local markets. Amaranthus viridis leaves and young plants (before they come into flower) are occasionally eaten as a cooked vegetable. The plant is also a good cattle fodder and green manure. The leaves are diuretic and purgative, and are used in poultices (fresh or as dried powder) to treat inflammations, boils and abscesses, gonorrhea, orchids and hemorrhoids. In Nigeria, an infusion of the whole plant is used to purify the blood and the pounded root is applied against dysentery. Amaranthus Viridis contain amino acids like lysine, arginine, histidine, cystine, phenylalanine, leucine, isoleucine, valine, threonine, methionine, tyrosine, etc. It also contains biologically active constituents like saponins, tannins and phenols, flavonoids, alkaloids, cardiac glycoside, steroid and triterpenoids and have some chemical constituent that exhibits potent antiinflammatory, antihepatotoxic, antiulcer antiallergic, antiviral actions. This is also used in Indian and Nepalese traditional system to reduce labour pain and act an antipyretic. The Negritos of the Philippines apply the bruised leaves directly to eczema, psoriasis, etc. and other traditional uses range from an anti-inflammatory agent of the urinary tract, venereal diseases vermifuge, diuretic, anti-rheumatic, antiulcer, analgesic, antiemetic, laxative, improvement of appetite, antiepileptic, treatment of respiratory, eye problems and asthma respectively (Reyad-ul-Ferdous et al. 2015). Also, some of the problems encountered by Amaranth growers include decreasing soil fertility and quantity of manure required for optimum crop productivity (Sanni, 2016; Adeyemi, Komolafe \& Akindele, 1989). Moreover, inadequate supply of chemical fertilizer and lack of capital to buy them in other countries are some of the problems (Adeyemi, Komolafe \& Akindele, 1989; Olufolaji et al. 1987). Synthetic Chemical fertilizers, which we provide to plant as plant nutrient, are harmful for the soil health. Therefore, there is, need to find an alternative for these synthetic fertilizers. The only solution for this problem is use of organic fertilizers, which is called as "Organic Farming. "Itis not a new concept of farming, it is been practiced in India since thousands of years. Agriculture is practiced by using organic technique, where the fertilizers, pesticides, etc., were obtained from plant and animal products.

Organic farming works at grass root level preserving the reproductive and regenerative capacity of the soil, good plant nutrition and produces nutritious food rich in vitality, which has resistance to diseases. Due to high prices of inorganic inputs, organic forming has become the main motivating factor for farmers in India. Thus, the farmers are being encouraged to grow organic produces. Successful organic crop production is still seeming to be a big challenge before farmers. This type of farming is often presented as a more biodiversity-friendly practice, but the generality of beneficial effects of organic farming is debated, as the effects appear often species and context dependent. Keeping these in view, the current research 
has highlighted the need to quantify the relative effects of local and landscape scale management on farmland biodiversity. The investments in agriculture went on increasing whereas the yields had constantly decreased which pushed the farmers into debt trap. The excessive use of chemicals has polluted water, soil, and environment. The modern agriculture has become cost intensive and the soil has become unproductive because of indiscriminate use of chemicals. The mono cropping and mechanization of farm equipment have affected the cattle population, which again led to infertile soils. In this backdrop, to overcome crisis in Agriculture and to ensure survival of small farmer, the only solution is organic fertilizers that builds humus in the soil and improves soil fertility Therefore, there is need to investigate into locally available, cheap organic fertilizers for vegetable production.

\section{Jeevamrutham}

Jeevamrutham is a culture, which enhances microbial activity in soil and thereby improves soil fertility and makes crops healthy. It is prepared using local cow dung, cow urine, jiggery, and pulses flour. It improves local earthworm activity and if used regularly as per protocol it replaces chemical pests and fertilizers efficiently

\section{Literature Review}

Organic farming has its roots in traditional agricultural practices that evolved in countless villages and farming communities over the millennium (Veni et al. 2020). The organic farming systems are diverse and occur throughout the world. In many countries organic farming now has a clear legislative basis and certification schemes for production and processing (Stockdale et al. 2001). Furthermore, to sustain soil health and benign environment there is a need for standardization. The conjunctive use of organic sources and biofertilizers is to increase the productivity and alternately improving soil health (Bahadur et al. 2006). Organic liquid fertilizer is the product of fermentation process, constituting efficient living soil. Moreover, the microorganisms and improves plant growth, productivity through supply of easily utilizable nutrients. Such fertilizers are cost effective and eco-friendly bioinoculants having great potential to enhance agricultural production in sustainable way. Biofertilizers are grouped into different types based on their function such as nitrogen fixing, phosphate solubilizing and other plant growth promoting biofertilizers by different mechanism. Nutrient uptake increases significantly and consistently with addition of organic manures. From the chemical point of view, the use of organic fertilizers such as cattle manure, maintains or increases soil organic matter contents and provides plants with nutrients However, very high rates may disturb the balance between nutrients and increase salt contents in the soil, which can hamper vegetable yields.

Leafy vegetables, as well as other vegetables, are considered nutrient-demanding because they require relatively large amounts in a relatively short period of time 
.Thus, applications of high rates of organic and mineral fertilizers are common in the cultivation of leafy vegetables Jeevamrutham is the best alternative that we can use in place of chemical fertilizer. Jeevamrutham is completely organic and can be used in the organic farming. Jeevamrutham serves as the rich source of the microorganism that fixes nitrogen, solubilize phosphorus. Also, it is the rich source of carbon, nitrogen, phosphorus, potassium and many micronutrients (Devakumar et al. 2014; Sreenivasa et al. 2010). Jeevamrutham is the rich source of the beneficial micro-organism such as nitrogen fixing and phosphate solubilizing bacteria. Moreover, it was found that Jeevamrutham is efficiently used between $8^{\text {th }}$ and $12^{\text {th }}$ days of preparation. The addition of such organic liquid manure would help to improve efficient microbial consortia thereby increasing NPK content and plant growth promoting factors. The use of Jeevamrutham is the best alternative to chemical fertilizer and our bio-enhancer could be potent source to improve soil fertility, crop productivity and quality (Kulkarni \& Gargelwar, 2019).

\section{Relevance}

Amaranthus Viridis has been selected as the test crop because they are the most commonly consumed leafy vegetables by 86 percent of the population in a country like India. Hence, the study has selected this particular leafy vegetable for wider understanding.

\section{Objective}

To assess the beneficial effects of Jeevamrutham in organic farming and especially towards cultivation of leafy vegetables

\section{Materials \& Methods}

\section{Preparation of Jeevamrutham (10Litres)}

The preparation shall be made by taking a container and place the mixed $0.5 \mathrm{~kg}$ cow dung, $500 \mathrm{ml}$ cow urine, $100 \mathrm{mg}$ jaggery and $100 \mathrm{mg}$ basin powder in 2.5 litres water then stir the contents with stick to 7 litres of water so as to prepare 10 litre of liquid Jeevamrutham. Keep, this container outside under the shade/under the tree covered with a cotton cloth is covered on it. Also, stir the liquid in the container every day in the morning and evening for about 15 minutes. Jeevamrutham is made in 48 hours and can be used directly to plants. The vegetables were cultivated in a randomized block design with two replicates each with 1.5-cent plot area. They were cultivated along with control, which is of normal soil. Initially, the soil plot is divided into two sub-replicates. One plot is sprinkled with normal tap water and labeled as control. The second plot is sprinkled with Jeevamrutham and labeled as test. After one hour, the seeds of green amaranth are weighed equally for the two plots and sown at the same time. The seeds of green amaranth (Amaranthus Viridis) 
were purchased from the Department of Agriculture, Nellore District, Andhra Pradesh.

\section{Biometrical Analysis \& Yield Attribute}

The green amaranth biometric analysis such as Biomass, plant height (shoots \& root length) was measured at 10 days interval. Furthermore, at each observation 20 plants were randomly selected and recorded.

\section{Soil Physico-Chemical Analysis}

The soil from various treatments such as control and Jeevamrutham applied soil are analyzed for physic-chemical properties such as $\mathrm{pH}, \mathrm{EC}, \mathrm{N}, \mathrm{P}, \mathrm{K}$, and $\mathrm{OC}$ (organic carbon).

$>\mathrm{P}^{\mathrm{H}}$ and conductivity- $\mathrm{P}^{\mathrm{H}}$ Meter

$>$ Organic Carbon by Rapid Titration Method (Walkley \& Black, 1947)

$>$ Nitrogen- Kjeldahl procedure (Cole \& Parks,1946)

$>$ Phosphorous- Dilute Acid-Fluoride Bray and Kurtz P-1 Method (Tandon, Motto \& Kurtz, 1967)

$>$ Potassium- Flame photometry (Murugesan \& Rajakumari, 2019)

$>$ The microbial analyses of soils (such as control, Jeevamrutham applied soil) were done by using standard viable count technique using hemocytometer or a digital colony counter.

$>$ The media such as, yeast extract manitol agar medium with Congo red for Rhizobium, Azospirillum isolation Jensen's medium, Actinomycetes isolation agar medium were used for the enumeration of the total bacteria, Rhizobium, Azospirillum and Actinomycetes. All the experimental analyses were carried out in triplicates and the average value was used in these studies.

\section{Analysis of Phytohormone}

Quantity of phytohormone like indole acetic acid (IAA), Gibberlic acid (GA), kinetin 3 and Abscisic acid in the manure samples by modified extraction method proposed by Unyayar, Topcuoglu and Unyayar in 1996.

\section{Results\& Interpretations}

The experimental results are categorically indicated in below tables and interpreted accordingly. 
Table 1: Impact of Jeevamrutham on Soil Quality

\begin{tabular}{|c|c|c|c|c|}
\hline S. No. & Parameter & Control & $\begin{array}{c}\text { Jeevamrutham } \\
\text { Treated }\end{array}$ & $\begin{array}{c}\text { Increase or Decrease } \\
\text { over Control } \\
\text { (Percentage) }\end{array}$ \\
\hline 1. & PH & $8.0 \pm 0.2$ & $7.7 \pm 0.02$ & $-3.75(\mathrm{p}<0.01)$ \\
\hline 2. & EC & $0.04 \pm 0.001$ & $0.18 \pm 0.7$ & $+350(\mathrm{p}<0.0001)$ \\
\hline 3. & N & $0.05 \pm 0.012$ & $1.96 \pm 0.23$ & $+3836(\mathrm{p}<0.00001)$ \\
\hline 4. & P & $17.8 \pm 0.71$ & $20.0 \pm 1.01$ & $+12.36(\mathrm{p}<0.001)$ \\
\hline 5. & K & $116 \pm 4.6$ & $127 \pm 8.7$ & $+9.48(\mathrm{p}<0.01)$ \\
\hline 6. & Organic Carbon & $7.80 \pm 0.7$ & $24.50 \pm 2.3$ & $+214.10(\mathrm{p}<0.0001)$ \\
\hline 7. & Moisture Content & $8.6 \pm 1.8$ & $18.4 \pm 0.34$ & $+113.95(\mathrm{p}<0.0001)$ \\
\hline
\end{tabular}

(Mean, \pm S.D. + or - indicate percent change over control. Values are mean of 10 observations. 'p' denotes the level of significance and N.S. No significance)

The data on the impact of Jeevamrutham on the soil quality is presented in Table 1. It has been found that there is a significant increase in EC $(+350), \mathrm{N}(+3836), \mathrm{P}$ $(+12.36), \mathrm{K}(+9.48)$, organic carbon $(+214.10)$ and moisture content $(+113.95)$.

Table 2: Impact of Jeevamrutham on Microbial Analysis

\begin{tabular}{|c|c|c|c|c|}
\hline $\begin{array}{c}\text { S. } \\
\text { No. }\end{array}$ & Parameter & Control & Experimental & $\begin{array}{c}\text { Increase or Decrease } \\
\text { over Control } \\
\text { (Percentage) }\end{array}$ \\
\hline 1. & Total viable count & $170 \times 10^{6}$ & $290 \times 10^{6}$ & 70.59 \\
\hline 2. & Rhizobium & $71 \times 10^{6}$ & $177 \times 10^{6}$ & 147.89 \\
\hline 3. & Azospirillum & $20 \times 10^{6}$ & $125 \times 10^{6}$ & 525 \\
\hline 4. & Actinomycetes & $18 \times 10^{6}$ & $42 \times 10^{6}$ & 133.33 \\
\hline
\end{tabular}

(Mean, \pm S.D. + or - indicate percent change over control. Values are mean of 10 observations. 'p' denotes the level of significance and N.S. No significance)

The data on the impact of Jeevamrutham on the soil microbial content is presented in Table 2. The results revealed that there is a significant increase in total viable count (70.59), Rhizobium (147.89), Azospirillum (525) and Actinomycetes (133.33).

Table 3: Impact of Jeevamrutham on Phytohormones

\begin{tabular}{|c|c|c|c|c|}
\hline $\begin{array}{c}\text { S. } \\
\text { No. }\end{array}$ & Phytohormone & Control & Experimental & $\begin{array}{c}\text { Increase or Decrease } \\
\text { over Control } \\
\text { (Percentage) }\end{array}$ \\
\hline 1. & IAA & $0.459 \pm 0.23$ & $3.0 \pm 0.34$ & $+553.59(\mathrm{p}<0.0001)$ \\
\hline 2. & GA3 & $0.554 \pm 0.033$ & $0.77 \pm 0.06$ & $+40.43(\mathrm{p}<0.001)$ \\
\hline 3. & ABA & $0.001 \pm 0.0001$ & $0.778 \pm 28.8$ & $+77700(\mathrm{p}<0.000001)$ \\
\hline 4. & Kinetin & $0.001 \pm 0.00011$ & $0.477 \pm 0.034$ & $+47600(\mathrm{p}<0.001)$ \\
\hline
\end{tabular}

(Mean, \pm S.D. + or - indicate percent change over control. Values are mean of 10 observations. 'p' denotes the level of significance and N.S. No significance) 
The data on the impact of Jeevamrutham on the soil phytohormone content is presented in Table 3. The results indicated that there is a significant increase in indole acetic acid (+553.59), Gibberlic acid $(+40.43)$, kinetin $(+47600)$ and Abscisic acid (+77700).

Table 4: Yield Attributes of Green Amaranth in Various Soil Samples

\begin{tabular}{|c|c|c|c|c|}
\hline $\begin{array}{c}\text { S. } \\
\text { No. }\end{array}$ & Parameter & Control & $\begin{array}{c}\text { Jeevamrutham } \\
\text { Treated }\end{array}$ & $\begin{array}{c}\text { Increase or Decrease } \\
\text { over Control } \\
\text { (Percentage) }\end{array}$ \\
\hline 1. & Biomass $(\mathrm{gms})$ & $10 \pm 1.1$ & $18 \pm 1.8$ & $80(\mathrm{p}<0.001)$ \\
\hline 2. & Shoot length $(\mathrm{cm})$ & $3.6 \pm 0.3$ & $4.3 \pm 0.34$ & $19.44(\mathrm{p}<0.001)$ \\
\hline 3. & Root lengh $(\mathrm{cm})$ & $0.65 \pm 0.1$ & $1.1 \pm 0.25$ & $69.23(\mathrm{p}<0.001)$ \\
\hline
\end{tabular}

(Mean, \pm S.D. + or - indicate percent change over control. Values are mean of 10 observations. 'p' denotes the level of significance and N.S. No significance)

The data on the impact of Jeevamrutham on the yield attributes is presented in Table 4 . The results showed that there is an increase in total biomass $(+80)$, shoot length (+19.44) and root length (+69.23).

\section{Discussion}

Jeevamrutham includes two words "Jeeva" and "Amrutham" which are derived from Sanskrit and are the most used by Hindus. The word "Jeeva" means a living organism and the word "Amrutham" stands for an elixir of life which has the capability to extend the life of any living organism. It is one of the best ways for the improvement of the number of microorganisms. Organic liquid fertilizer is the product of fermentation process, constituting efficient living soil microorganisms and improves plant growth, productivity through supply of easily utilizable nutrients. Such fertilizers are cost-effective and eco-friendly bio-inoculants shaving great potential to enhance agricultural production in sustainable way. Biofertilizers are grouped into different types based on their functions such as nitrogen fixing, phosphate solubilizing and other plant growth promoting bio-fertilizers by different mechanism. The excessive use of the chemical fertilizer has disadvantage over the fertility of the soil. Jeevamrutham is the best alternative that we can use in place of chemical fertilizer. Jeevamrutham is completely organic and can be used in the organic farming. Jeevamrutham serves as the rich source of microorganism that fixes nitrogen, solubilize phosphorus, also it is the rich source of carbon, nitrogen, phosphorus, potassium and many micronutrients. Jeevamrutham is low cost improvised preparation that enriches the soil with indigenous microorganism required for mineralization from native cow dung, cow urine, horsegram and jiggery. The Jeevamrutham in acidic soil when applied increases $\mathrm{pH}$ and in alkaline soil decreases $\mathrm{pH}$. Thus, creates favorable condition for availability of maximum nutrients to plants, pH6.5 to 7.8. This condition increases the crop yield and cuts 
down the entire expenses of chemical fertilizer. The plant growth promoting Rhizo bacteria, Bacillus Pumillus and Bacillus Licheniformis produce high amount of physiologically active Gibberellins Copious amount of Jeevamrutham can be used for best results. The environment which is ideal for the microorganisms to survive is that the soil temperature which is in between $24^{\circ} \mathrm{C}$ to $30^{\circ} \mathrm{C}$, the humidity of 88 percent and maintaining moisture in the soil. This type of climate is available only in the monsoons, wherein in one can also make this happen through mulching. Mulching will help in the creation of micro-environment which will help in the improvement of microorganisms, which will, in turn, result in the formation of humus. Fermentation of organic manure as in Jeevamrutham would help to remove lignin, tannic acid, oil which are present in plant based organic raw material and are harmful to root sand inhibit the growth. However, fermenting the organic raw material might eliminate the problem. For the fermentation of fertilizer comparatively dry materials are mixed with very wet materials to obtain the preferred moisture content at a given mass. Furthermore, the aeration is very necessary factor for quality fermentation to take place. At the early stage of fermentation, a lot of oxygen is required. The effect of oxygen shortage and excessive carbondioxide can be very serious. The optimal period of fermentation can be 40 days. According to him, greater availability of nutrients occurs with a longer period of fermentation because in short period sufficient decomposition of biofertilizer does not occur to release nutrients. Jeevamrutham is a most efficient biofertilizer in the enrichment of soil nutrients, improvement of biomass, root length, shoot length, maintenance of soil texture and soil microbial quality and Phytohormones etc., and indicated the factors that influence the growth of the plant and production of high yield (Moreira et al. 2018). The important effect of Jeevamrutham is stimulation and growth of fine hair roots. Plants sprayed with Jeevamrutham invariably produce bigger leaves and denser canopy (Bama \& Somasundaram, 2017). Jeevamrutham serves as the rich source of the microorganism that fixes nitrogen, solubilize phosphorus and also it is the rich source of carbon, nitrogen, phosphorus, potassium and many micronutrients (Devakumar et al. 2014, Sreenivasa, Naik \& Bhat, 2010). Jeevamrutham is low cost improvised preparation that enriches the soil with indigenous microorganism required for mineralization from native cow dung, cow urine, horse gram and jiggery (Gores \& Sreenivasa, 2011). Jeevamrutham in acidic soil when applied increases $\mathrm{pH}$ and in alkaline soil decreases $\mathrm{pH}$. Thus, it creates favorable condition for availability of maximum nutrients to plants with $\mathrm{pH}$ ranging from 6.5 to 7.8. This condition increases the crop yield and cuts down an entire expense of chemical fertilizer. The plant growth promoting Rhizobacteria, Bacillus Pumilus and Bacillus Licheniformis produce high amount of physiologically active Gibberellins. Moreover, the higher microbial population of the liquid formulation made them as potent source to maintain soil fertility and to enhance the nutrient availability in faster decomposition of bulky organic manures. 


\section{Suggestions}

Jeevamrutham can be used as efficient organic fertilizer for rowing amaranths viridis. It can be used to increase the availability of high-quality Amaranths throughout the year. It minimizes the purchase chemical fertilizer during farming.

\section{Conclusion}

Jeevamrutham is the rich source of the beneficial micro-organism such as nitrogen fixing and phosphate solubilizing bacteria. It has been observed from the study that Jeevamrutham is an efficient organic fertilizer, which improves soil quality. The addition of such organic liquid manure would help to improve the microbial content thereby increasing NPK content and plant growth promoting factors. The use of Jeevamrutham is the best alternative to chemical fertilizer.

\section{References}

Adeyemi, I. A., Komolafe, A. \& Akindele, A. O. (1989). Properties of Steam Blanched Maize Flour as a Constituent of Weaning Food, Journal of Food Processing and Preservation, Vol.13, No.2, pp.133-144.

Bahadur, A., Singh, J., Singh, K. P. \& Rai, M. (2006). Plant Growth, Yield and Quality Attributes of Garden Pea as Influenced by Organic Amendments and Biofertilizers, Indian Journal of Horticulture, Vol.63, No.4, pp.464-466.

Bama, K. S. \& Somasundaram, E. (2017). Soil Quality Changes under Different Fertilization and Cropping in a Vertisol of Tamil Nadu, International Journal of Chemical Studies, Vol.5, No.4, pp.1961-1968.

Cole, J. O. \& Parks, C. R. (1946). Semimicro-Kjeldahl Procedure for Control Laboratories, Industrial \& Engineering Chemistry Analytical Edition, Vol.18, No.1, pp.61-62.

Devakumar, N., Shubha, S., Gowder, S. B. \& Rao, G. G. E. (2014). Microbial Analytical Studies of Traditional Organic Preparations Beejamrutha and Jeevamrutha. In: Rahmann, G. and Aksoy, U. (Eds.) Building Organic Bridges, Johann Heinrich Von Thünen-Institut, Braunschweig, Germany, 2, Thuenen Report, No.20, pp.639-642.

Gore, N. S. \& Sreenivasa, M. N. (2011). Influence of Liquid Organic Manures on Growth, Nutrient Content and Yield of Tomato (Lycopersicon Esculentum Mill.) in the Sterilized Soil, Karnataka Journal of Agricultural Sciences, Vol.24, No.2, pp.153-157. 
Kulkarni, S. S. \& Gargelwar, A. P. (2019). Production and Microbial Analysis of Jeevamrutham for Nitrogen Fixers and Phosphate Solubilizers in the Rural Area from Maharashtra, IOSR Journal of Agriculture and Veterinary Science, Vol.12, No.8, pp.85-92.

Moreira, W. K. O., Borrajo, F. D., De Sousa, S. K. A., Cardoso, G. G., Da Silva Luz, A. L., Da Silva, R. T. L. \& De Olivera Neto, C. F. (2018). Methods of Soil Management and Depths of Sowing in Corn Cultivation, Journal of Agricultural Science, Vol.10, No.6, pp.299-309.

Murugesan, A. G. \& Rajakumari, C. (2019). Environmental Science and Biotechnology: Theory and Techniques, MJP Publisher, Chennai, 474p.

Olufolaji, A. O., Tayo, T. O., Kayode, P. A. \& Adeyemi, M. (1987). Analysis of Leaf Appearance, Expansion, and Duration in Amaranthus, Annual Report, National Horticultural Research Institute, Ibadan, Nigeria.

Reyad-ul-Ferdous, M., Shamim Shahjahan, D. M., Tanvir, S. \& Mukti, M. (2015). Present Biological Status of Potential Medicinal Plant of Amaranthus Viridis: A Comprehensive Review, American Journal of Clinical and Experimental Medicine, Vol.3, No.5-1, pp.12-17.

Sanni, K. O. (2016). Effect of Compost, Cow Dung and NPK 15-15-15 Fertilizer on Growth and Yield Performance of Amaranth (Amaranthus Hybridus), International Journal of Advances in Scientific Research, Vol.2, No.3, pp.76-82.

Sreenivasa, M. N., Naik, N., \& Bhat, S. N. (2010). Beejamrutha: A Source for Beneficial Bacteria, Karnataka Journal of Agricultural Sciences, Vol.22, No.5, pp.1038-1040.

Stockdale, E. A., Lampkin, N. H., Hovi, M., Keatinge, R., Lennartsson, E. K. M., Macdonald, D. W. \& Watson, C. A. (2001). Agronomic and Environmental Implications of Organic Farming Systems, Advances in Agronomy, Vol.70, pp.261327.

Tanaka, Y \& Van Ke, N. (2007). Edible Wild Plants of Vietnam: The Bountiful Garden, Orchid Press, Thailand, p.24.

Tandon, H. L. S., Motto, H. L. \& Kurtz, L. T. (1967). Composition of Dilute - Acid - Fluoride (Bray P1) Extracts of Illinois Soils, Soil Science Society of America Journal, Vol.31, No.2, pp.168-171. 
Unyayar, S., Topcuoglu, S. F. \& Unyayar, A. (1996). A Modified Method for Extraction and Identification of Indole-3-Acetic Acid (IAA), Gibberellic Acid (GA3), Abscisic Acid (ABA) and Zeatin produced by Phanerochaetechrysosporium ME446, Bulgarian Journal of Plant Physiology, Vol.22, No.3-4, pp.105-110.

Veni, V. G., Srinivasarao, C., Reddy, K. S., Sharma, K. L. \& Rai, A. (2020). Soil Health and Climate Change, In: Majeti Narasimha Vara Prasad, M. N. V. \& Pietrzykowski, M. (Eds.) Climate Change and Soil Interactions, Elsevier, USA, Vol.1, pp.751-767.

Walkley, A. \& Black, I. A. (1947). A Critical Method for Determining Organic Carbon in Soils, Effects of Variation in Digestion Conditions and of Organic Soil Constituents, Soil Science, Vol.63, No.4, pp.251-26. 